\title{
POŠTA
}

TELEKOMUNIKACIE A

ELEKTRONICKY OBCHOD

\section{PERSPEKTÍVA PRODUKTOV NEŽIVOTNÉHO POISTENIA V RÁMCI ELEKTRONICKÉHO POISŤOVNÍCTVA 1/3}

\author{
Martina Kováčiková*
}

\section{Úvod}

Poistný trh má v trhovej ekonomike významné postavenie so špecifickými úlohami, princípmi a významom. Je to miesto kde sa obchoduje s poistnou ochranou. Tento trh ovplyvňuje každého člena spoločnosti, či už priamo, alebo nepriamo. Poist'ovníctvo poskytuje na poistnom trhu špecifický tovar - poistenie. Zasahuje do všetkých činností národného hospodárstva - do života občanov i štátu, do podnikatel'skej sféry. Dôležité miesto má aj v medzinárodnom obchode v súvislosti s poistením medzinárodných rizík.

S neustálym rozvojom internetu a internetových služieb sa aj v oblasti poist'ovníctva stále viac produktov poskytuje elektronickou formu. Ciel'om poist'ovacích inštitúcií je znižovat' náklady a poskytovat' služby s väčším ziskom. Jednou z možností je využitie internetu.

Prvá čast' súvisiacich článkov je venovaná charakteristike životného a neživotného poistenia. V rámci druhej časti bude rozpracované elektronické poist'ovníctvo. V tretej časti bude prezentovaný možný návrh produktu pre elektronické poist'ovníctvo, koncipovaný na základe vykonaného dotazníkového výskumu.

\section{Typy poistení, životné neživotné poistenie}

Poistenie je ekonomická a právna kategória. Z toho pohl'adu musí mat' poistenie ako ekonomicko - právny vzt'ah dva obsahy a to:

o ekonomický,

o právny.

Ak má byt' poistenie zmysluplné, potom je nevyhnutné, aby boli obidva obsahy naplnené vo vzájomnej väzbe, pretože v opačnom prípade stráca poistenie zmysel.

Pre lepšiu orientáciu v niekol'kých stovkách poistných produktov sa na základe niekol'kých spoločných čŕt vytvorila ich kategorizácia. [2]

Podl'a zákona o poist'ovníctve poistné produkty začleňujeme do

o poistných druhov,

o poistných odvetví,

o poistných skupín.

Poistné druhy znamenajú rozdelenie poistných produktov na životné poistenia a neživotné poistenia.

\section{1. Životné poistenie}

\footnotetext{
* Ing. Martina Kováčiková, PhD., Žilinská univerzita v Žiline, Fakulta prevádzky a ekonomiky dopravy a spojov, Katedra Spojov, Univerzitná 1, 01026 Žilina, Slovenská republika, tel.: +421 415133 123, E-mail: martina.kovacikova@fpedas.uniza.sk
} 
Životné poistenie predstavuje jedno z odvetví poist'ovníctva. Jeho význam narastá súmerne s posilňovaním ekonomiky príslušnej krajiny a príjmov jeho obyvatel'stva. Životné poistenie je finančným produktom kryjúcim riziko smrti. Pretože disponuje vel'kou variabilitou je v poslednej dobe využívané najčastejšie v spojitosti so sporením. Uzavretie dobrého životného poistenia je vel'mi dôležitým rozhodnutím, ktoré nie je dobré uskutočnit' bez predchádzajúceho prieskumu a správneho výberu. Ked' má životné poistenie zabezpečit' krytie životných rizík v dostatočnej výške, väčšinou sa nejedná o lacný produkt. Zle vybraté životné poistenie nielenže nepokryje všetky riziká, ale stane sa tiež neefektívnym vyhadzovaním peňazí. Životné poistenie sa spája s poistením osôb. Riziká ktoré existujú v životnom poistení sú :

o smrt' poisteného,

o dožitie určitého veku poisteného,

o invalidita poisteného.

\subsection{Neživotné poistenie}

Neživotné poistenie je samostatným poistným odvetvím, do ktorého patrí poistenie majetku. Poistit' sa môže hnutel'ný, či nehnutel'ný majetok. Je označované ako rizikové poistenie, v ktorom poist'ovatel' jednoznačne nevie, či poistná udalost' vznikne alebo nie a či bude poskytovat' poistné plnenie a v akej výške. Poistné odvetvie neživotného poistenia je založené na princípoch podmienenej návratnosti. Technická rezerva sa stanovuje podl'a rozsahu poistného rizika, pravdepodobnosti vzniku poistnej udalosti a rozsahu škôd, ktoré nastali.[3]

Neživotné poistenie zahŕňa krytie rizík, ktoré vedú ku škodám na poistených predmetoch, t.j. k poškodeniu, strate, zničeniu alebo finančným stratám. Subjektmi v poistení majetku sú právnické a fyzické osoby, pri ktorých rozoznávame poistenie fyzických podnikajúcich osôb a súkromných osôb. Neživotné poistenie zahrňuje krytie rizík, s ktorým sa osoby pri svojej činnosti stretávajú a ktoré možno podl'a dôsledkov rozdelit' na:

a) riziká, pri ktorých dochádza k vzniku priamych finančných škôd:

o živelné riziká - predstavujú široké spektrum rizík priamych škôd na majetku spôsobených živelnými udalost’ami (napr. požiar, výbuch, blesk, víchrica, povodeň, záplava, atd’.),

o vodovodné riziká - spôsobené vodou vytekajúcou z vodovodných zariadení, kanalizácií a vykurovacích telies,

o riziká havárie - kde sa rozlišujú riziká majetkových škôd tak na dopravných prostriedkoch, ako aj na prepravovanom náklade,

o riziká odcudzenia a vandalizmu - súvisiace so zásahom tretej osoby,

o riziká prevádzky strojov a strojových zariadení - nastanú v dôsledku havárií či porúch strojov chybnou technológiou, neodborným zásahom, skratom elektrického prúdu, atd'..

b) riziká, pri ktorých dochádza k vzniku následných finančných strát:

o riziká prerušenia prevádzky - ktoré vznikli v dôsledku prerušenie prevádzky alebo výroby v dôsledku živelnej udalosti, havárie, výpadku dodávky energie, atd',

o úverové riziká - súvisiace s neplatením úveru v dôsledku nesolventnosti, platobnej nevôle dlžníka alebo vonkajších podmienok, ked' nie je možné dlžobu zaplatit'.

c) riziká, ktoré vplývajú na finančnú stabilitu poisteného: 
o riziká zodpovednosti za finančné škody voči tretím osobám - kde príjemcom poistného plnenia je tretia osoba stojaca mimo zmluvného vzt'ahu poist'ovne a poistného,

o riziká zodpovednosti za škody na živote a zdraví tretích osôb - kde je odškodňovaná strata na živote a zdraví tretích osôb. Nakol'ko nejde o odškodňovanie majetkových škôd, je pri tomto poistení prítomný prvok životného poistenia.

\section{d) riziká súvisiace $\mathrm{s}$ ujmou na zdraví poisteného:}

o ide o riziká, ktoré svojou poistno-technickou konštrukciou patria do neživotného segmentu, ale svojím obsahom úzko súvisia s rizikom ujmy na zdraví človeka. Z ekonomického hl'adiska znamenajú stratu na príjmoch, teda sú príbuzné a často zlučované so životnými rizikami. Prvok neživotného poistenia sa nachádza v rizikovej zložke poistenia.

Jednotlivé poistenia v neživotnom poistení vznikajú na základe existencie rizík súvisiacich s každodennými životnými potrebami, ako aj so samotným rozhodnutím poisteného, ktoré riziká chce maž poistením kryté.

Poistenia sa delia najmä podl'a:

o poistených rizík - napr. poistenie živelných rizík, poistenie proti požiaru, havarijné poistenie, atd',

poistených majetkových predmetov či záujmov - napr. poistenie domácnosti, motorových vozidiel, úverov a pod. [1]

\section{Produkty životného poistenia}

Poistný trh ponúka klientom rôzne druhy životného poistenia v podobe poistných produktov znázornených na obr. 1.

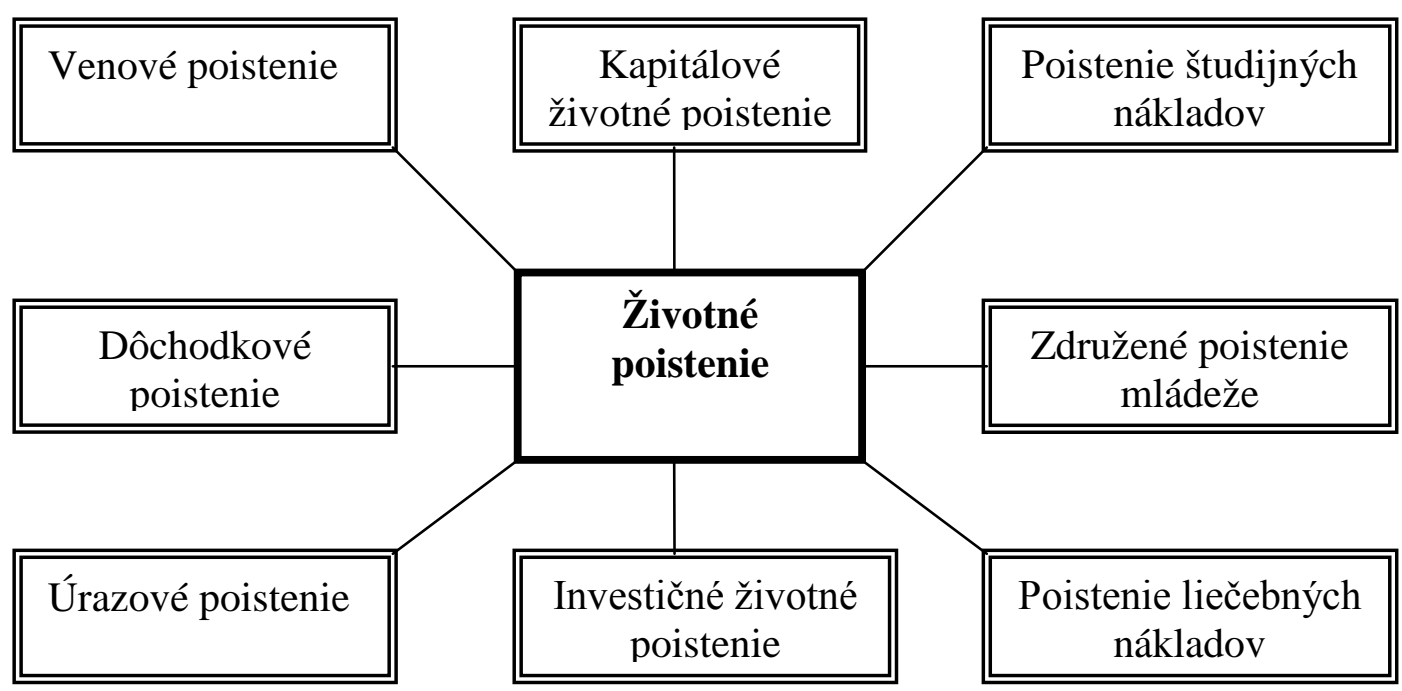

Obrázok 1. Klasifikácia produktov životného poistenia ( Zdroj: autor)

\section{Charakteristika vybraných produktov životného poistenia}


Životné poistenie sa označuje aj ako poistenie osôb. Pokial' má poist'ovňa vo svojom portfóliu životné poistenie, obvykle ponúka všetky jeho druhy v niekol'kých rôznych variáciách. V súčasnosti je na poistnom trhu na výber zhruba 300 základných variantov.

Medzi najčastejšie využívané životné poistenia sú :

o dôchodkové poistenie,

o investičné životné poistenie,

o kapitálové životné poistenie,

o životné poistenie pre prípad smrti,

o pripoistenia (napr. úrazové poistenie, ktoré sa používa ako pripoistenie k vyššie uvedeným poisteniam).

$\checkmark$ Dôchodkové poistenie - predstavuje doplnok k zákonnému dôchodkovému poisteniu. Má dobrovol'ný charakter, poskytuje širšiu poistnú ochranu, v rámci ktorej si poistený môže dohodnút' aj dočasný dôchodok. Poist'ovne ponúkajú širokú škálu dôchodkových poistení, súčast'ou ktorej sú najmä tieto poistné produkty:

o starobné poistenie ako poistenie na zabezpečenie príjmu v starobe a pre prípad úmrtia (zo systému starobného poistenia sa poskytuje starobný dôchodok, predčasný dôchodok, vdovský dôchodok, vdovecký dôchodok, sirotský dôchodok.),

o invalidné poistenie ako poistenie pre prípad poklesu schopnosti vykonávat' zárobkovú činnost' v dôsledku dlhodobo nepriaznivého zdravotného stavu poistenca a pre prípad úmrtia (zo systému invalidného poistenia sa poskytuje invalidný dôchodok, vdovský dôchodok, vdovecký dôchodok, sirotský dôchodok.) [1], [5]

$\checkmark \quad$ Investičné životné poistenie - je historicky najmladšie. Ide o transparentný produkt životného poistenia, ktorý poskytuje poistenému ochranu vo forme životného poistenia a zároveň buduje špeciálny (samostatný) investičný účet. Po celý čas trvania poistenia je poistenec poistený proti riziku nepriaznivej udalosti a súčasne má aj možnost' investovat'. Poistnou udalost'ou $\mathrm{v}$ investičnom životnom poistení je úmrtie poisteného, ked' je oprávneným osobám vyplatená suma zaplateného poisteného, resp. hodnota podielových jednotiek vedených na účte klienta, ak je táto hodnota vyššia.

[7]

Investičné životné poistenie by malo byt' dlhodobé, skôr je určené pre mladších l'udí.

$\checkmark$ Kapitálové životné poistenie - patrí k najstarším životným poisteniam a v súčasnosti aj k najrozšírenejším typom osobného poistenia. Je to kombinácia životného poistenia a dlhodobého investovania finančných prostriedkov. Tento typ poistenia je výhodnou a bezpečnou alternatívou ku klasickému sporeniu. Zhodnotenie je bezpečnejšie ako pri investičnom poistení, ale dost' nízke. Poistenie si môžu uzatvorit' l'udia vo veku od 15 do 65 rokov. [6]

$\checkmark$ Úrazové poistenie - ide o druh rizikového poistenia, ktorého predmetom je telesné poškodenie poisteného náhlymi a neočakávanými vplyvmi, ktoré pôsobia na poisteného zvonku. Úrazové poistenie sa môže dohodnút' ako pripoistenie ku väčšine rezervotvorných životných alebo dôchodkových poistení. Možno ho však uzatvorit' samostatne. Môže sa vzt’ahovat' na pracovné úrazy, mimopracovné úrazy, na všetky druhy úrazov, ktoré sa v každodennom živote poisteného môžu vyskytnút'. [1]

$\checkmark$ Poistenie pre prípad smrti - (často označované aj ako rizikové životné poistenie)

Poistnou udalost'ou je úmrtie poisteného. Rozlišujeme dva typy tohto poistenia:

o dočasné poistenie pre prípad smrti,

o trvalé poistenie pre prípad smrti.

Odlišnost' týchto typov poistenia spočíva $\mathrm{v}$ jeho tvorbe technických rezerv. Pri dočasnom poistení sa nevytvára rezerva poistného. Pri trvalom poistení sa vytvára rezerva poistného, pretože ide o doživotné poistenie, pri ktorom sa musí vyplatit' dohodnutá poistná 
suma v čase vzniku poistnej udalosti. Pri dočasnom poistení sa vypláca poistná suma len v prípade smrti poisteného, pokial' úmrtie nastane v priebehu poistnej doby. Na konci poistenia sa nevypláca žiadna poistná suma. [1]

\section{Produkty neživotného poistenia}

Podl'a klasifikácie neživotného poistenia, v súlade so zákonom o poist’ovníctve, možno jednotlivé poistné odvetvia na základe krytia rizík rozdelit’:

- poistenie úrazu,

- poistenie chorôb,

- poistenie majetku,

- poistenie živelných rizík,

- poistenie technických rizík,

- poistenie dopravné,

- poistenie krádeže,

- poistenie pol'nohospodárskych rizík,

- poistenie zodpovednosti za škodu,

- poistenie iných záujmov,

- poistenie finančných rizík.

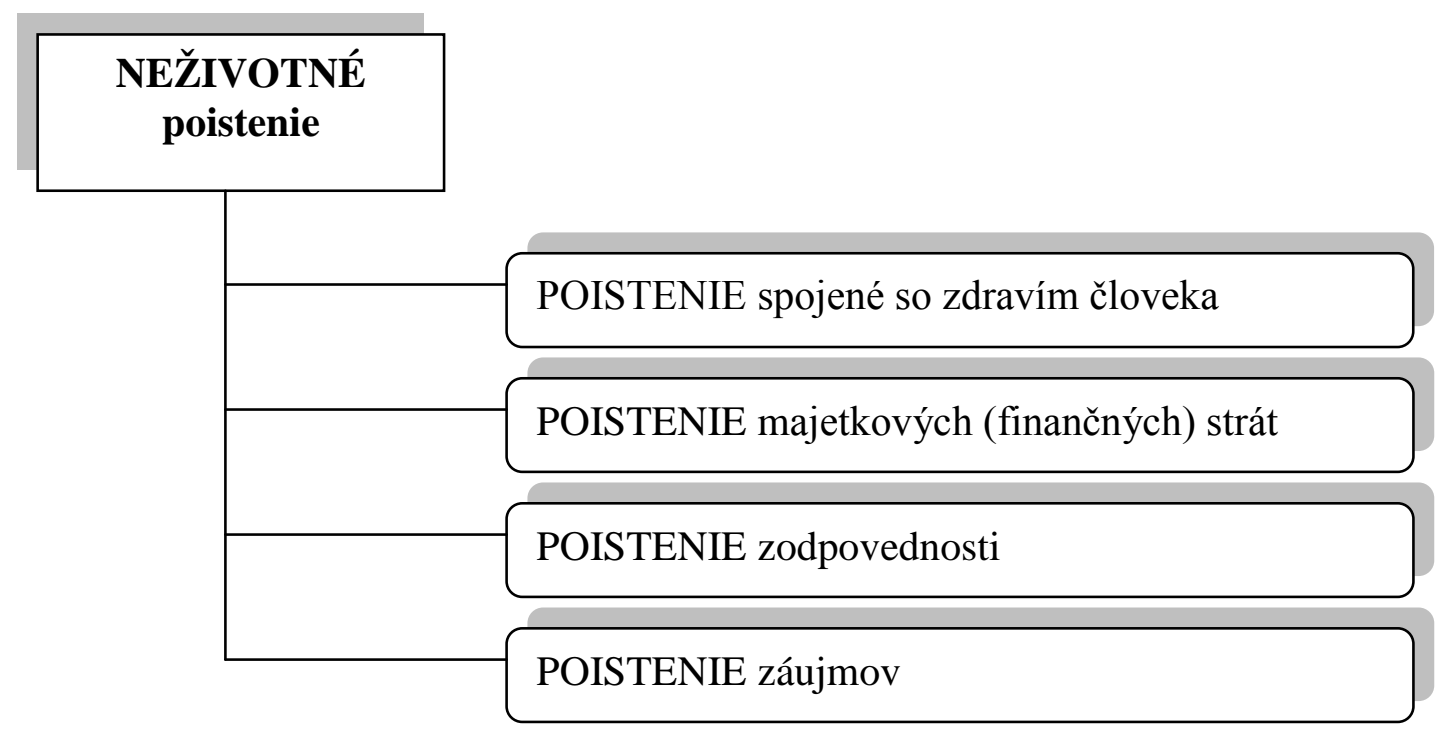

Obrázok 2. Členenie neživotného poistenia podl'a krytia rizík (Zdroj: Majtánová,A., Daňhel,J., Ducháčková,E., Kafková,E.: Poist'ovníctvo -Teória a prax, Praha: Ekopress, 2006, s.152)

\section{Charakteristika vybraných produktov neživotného poistenia}

Krytie poistitel'ných rizík v neživotnom poistení možno rozdelit' na dve vel'ké skupiny, t.j. individuálne poistenie a podnikatel'ské poistenie. $\mathrm{V}$ klientskom sektore obyvatel'stva dominujú produkty poistenia domácností, poistenia budov a poistenia motorových vozidiel. V poisteniach priemyselných a podnikatel'ských rizík okrem najčastejších produktov živelného, strojového poistenia, poistenia proti odcudzeniu, poistenia stavebného a montážneho, sú makroekonomicky najvýznamnejšími produktmi poistenie pre prípad prerušenia prevádzky podniku, poistenie úveru, poistenie dopravy a poistenie plodín.

$\checkmark$ Cestovné poistenie - je poistenie klientov pri zahraničných cestách mimo trvalého bydliska. V poistení býva okrem poistenia liečebných nákladov a asistenčných služieb 
združené poistenie majetku, zodpovednosti a úrazové poistenie. Poistná doby býva maximálne do jedného roka.

$\checkmark$ Poistenie domácností, bytových jednotiek a budov - predstavuje poistenie súboru vecí nachádzajúcich sa v domácnosti, t.j. poistenie sa vzt’ahuje na hnutel'né veci tvoriace zariadenie domácnosti, slúžiace na jeho prevádzku alebo k uspokojovaniu potrieb členov domácnosti. Súčast'ou poistenia sú aj predmety v priestoroch, ktoré nie sú súčast’ou bytu (napr. pivnica).

Poistenie domácností sa rozdel'uje na:

- poistenie domácnosti, v ktorej občan bežne býva,

- poistenie rekreačnej domácnosti, ktorá je obývaná len sporadicky.

Poistenie smeruje na krytie poistných udalostí spôsobených:

- živelnými udalost’ami,

- atmosferickými zrážkami,

- vodou z vodovodných a teplovodných zariadení,

- krádežou,

- vlámaním,

- zodpovednost’ou za škody spôsobené prevádzkou domácností a jej členmi,

- d’alšími rizikami.

Poistenie domácnosti sa dojednáva podl'a počtu obytných miestností a na poistnú sumu, ktorá limituje poistné plnenie.

K tomuto základnému poisteniu si môžeme pripoistit':

\section{poistenie zodpovednosti za škodu}

Poistenie sa vzt’ahuje na škody, ktoré môžu spôsobit' členovia domácnosti alebo domáce zvieratá tretej osobe pri bežných činnostiach. Toto poistenie kryje škody: vznikajúcej pri bežnej prevádzke domácnosti (vytopenie susedov); vznikajúce pri rekreácii a zábave; vzniknuté pri rekreačných športoch, ktoré môžeme spôsobit' ako chodec, cyklista; ktoré spôsobia domáce a drobné hospodárske zvieratá (pes pohryzie suseda, rozhryzie návšteve topánky.)

$\checkmark$ Poistenie bytových jednotiek a budov - orientuje sa bud’ na živelné udalosti, alebo sa uzatvára ako združené poistenie obsahujúce aj d'alšie riziká, ktoré môžu ohrozovat' poistenú budovu. Realizuje sa podl'a určenia a využitia poistenej budovy, čo určuje jej vybavenie a tým aj úroveň rizika. Riziko ovplyvňuje aj materiál, z ktorého je budova postavená a jej vybavenie.

K tomuto poisteniu je možné pripoistit' :

poistenie zodpovednosti za škodu vyplývajúcu z vlastníctva alebo držby budovy; z činnosti poisteného ako stavebníka; z prevádzky zariadení tejto budovy; zo svojpomocného vykonávania drobných stavebných prác na tejto budove, ku ktorým nie je potrebné stavebné povolenie. Poistenie sa vzt'ahuje na škody na zdraví, vrátane nákladov pri usmrtení, a na škody, ktoré vzniknú poškodením alebo zničením veci, vrátane ušlého zisku . [1]

$\checkmark$ Havarijné poistenie motorových vozidiel - poistenie pokrýva: poškodenie alebo zničenie motorového vozidla haváriou; poškodenie alebo zničenie vozidla prírodným živlom, odcudzenie vozidla; nadštandardnú výbavu; smrt' v dôsledku havárie; úrazové poistenie osôb v motorovom vozidle; batožinu a veci osobnej potreby. Poist'ovne neponúkajú havarijné poistenie ako jeden ucelený balík. Ponúkajú ho bud' ako stavebnicový systém, v ktorom si klient sám zvolí, čo si chce poistit, prípadne ho ponúkajú ako balíky produktov, ktoré obsahujú rôzne typy poistení. Pri havarijnom poistení je potrebné počítat' so zmluvne dohodnutou spoluúčast'ou, čiže určitou čast'ou škody, ktorú poist'ovňa nepreplatí. Spoluúčast' je daná percentom, prípadne aj minimálnou sumou, ktorú v prípade škôd musí znášat' klient. 
Toto poistenie nám ponúka aj poistenie ojazdených motorových vozidiel. Je určené pre vodičov, ktorí chcú cenovo výhodne poistit’ ojazdené vozidlo. Avšak v prípade poškodenia vozidla sú poistným plnením účelne vynaložené a primerané náklady na opravu stanovené poist'ovatel'om podl'a rozpočtu nákladov na opravu, znížené o sumu zodpovedajúcu veku vozidla v čase vzniku poistnej udalosti. [2]

$\checkmark$ Povinné zmluvné poistenie - povinné zmluvné poistenie zodpovednosti za škodu spôsobenú prevádzkou motorového vozidla je nevyhnutná, zákonom stanovená povinnost' každého motoristu. Spol'ahlivo poisteného klienta ochráni, ak prevádzkou svojho motorového vozidla spôsobí iným škodu. Základný limit poistného plnenia je maximálne 663878 Eur pre jedného poškodeného pri škodách na zdraví a usmrtení a 663878 Eur pri vecných škodách a ušlom zisku na jednu poistnú udalost'. Poistenie sa môže uzatvorit’ bez spoluúčasti, ale aj so spoluúčast'ou, ktorú privítali príležitostní vodiči, ktorí menej jazdia. [2]

$\checkmark$ Poistenie zodpovednosti za škody - poistenie zodpovednosti za škodu predstavuje jedno vel'ké a dôležité odvetvie, ktoré sa orientuje na poistnú ochranu poisteného a poškodeného. V prípade poisteného to znamená prenesenie časti alebo celej škody spôsobenej činnost'ou poisteného (a za ktorú poistený zodpovedá iným, tzv. tretím osobám na poist'ovňu. V prípade poškodeného ide o poskytnutie náhrady škody, ktorá mu bola spôsobená konaním inej (poistenej osoby), za ktorú táto osoba zodpovedá, a to až do výšky dohodnutej v poistnej zmluve. Z hl'adiska záväznosti sa poistenie zodpovednosti za škodu realizuje ako:

- povinné zmluvné poistenie,

- dobrovol'né zmluvné poistenie.

Do tohto odvetvia možno zahrnút':

- poistenie všeobecnej zodpovednosti za škodu,

- poistenie zodpovednosti za škodu občanov,

- poistenie zodpovednosti podnikatel'ov a škodu spôsobenú prevádzkovou činnost'ou a zodpovednosti za výrobok,

- poistenie profesijnej zodpovednosti,

- poistenie zodpovednosti za škody malých plavidiel a gumových člnov.

Poistenie zodpovednosti z prevádzky motorových vozidiel - toto poistenie má charakter zákonného poistenia uvedením motorového vozidla do prevádzky, ide o povinné zmluvné poistenie vozidiel. Poistenie kryje za poisteného všetky škody, ktoré sú spôsobené prevádzkou motorového vozidla. Poist'ovňa zároveň poskytuje poistenému právnu ochranu pri súdnom prerokúvaní spôsobenej ujmy v trestnom konaní. Poistenie sa vzt'ahuje na škody, ktoré použitím vozidla nespôsobil jeho vlastník, ale iná osoba. [4]

Poistenie zodpovednosti za škody spôsobené pri výkone povolania. Poistenie sa vzt'ahuje na škody, ktoré spôsobí zamestnanec svojmu zamestnávatel'ovi svojou činnost'ou vykonávanou v súvislosti s pracovnou činnost'ou, napr. neúmyselné poškodenie majetku zamestnávatel'a či spôsobenej inej ujmy.

$\checkmark$ Poistenie iných škôd vzniknutých krupobitím, mrazom alebo inými príčinami (napr. krádežou) - toto poistné odvetvie obsahuje poistenie iných rizík, ako tých, ktoré sú zahrnuté pod termín požiarne poistenie. Týmto poistením sa dopĺn̆a požiarne poistenie na poistnú ochranu pre prípad všetkých prírodných ale aj vybraných technických rizík. Obsahuje najmä:

- škody spôsobené l'adovcom,

- škody spôsobené námrazou a t’archou snehu,

- škody spôsobené atmosférickými zrážkami,

- škody spôsobené zemetrasením, zosuvom pôdy a lavínami,

- škody spôsobené zadymením, 
- Škody spôsobené vodou vytekajúcou z teplovodných a studenovodných zariadení,

- Škody spôsobené násilným pôsobením cudzích osôb,

- škody spôsobené technickými rizikami okrem havárie dopravných prostriedkov,

- škody spôsobené na skle,

- škody spôsobené na pol’nohospodárskej produkcii.

Touto skupinou rizík možno poistit' akýkol'vek poistný majetok.

$\checkmark$ Finančné poistenie - finančné poistenie predstavuje krytie rizík spojených s rôznymi finančnými stratami, ktoré z rôznych dôvodov môžu vzniknút' a nedotýkajú sa len priamych vecných škôd. Môže íst' o poistenie úverov, poistenie nečestného konania zamestnanca, klienta banky alebo inej finančnej inštitúcie, poistenie vkladov, poistenie platobných kariet a pod.

$\checkmark$ Poistenie psov - od júna 2007 je na slovenskom poistnom trhu novinkou poistenie psov. Štvornohých miláčikov chráni pre prípad úrazu či choroby, ich majitel'ov pred úhradou škôd, ktoré spôsobia na majetku i zdraví iných osôb. Každý pes, ktorému má byt' poistenie uzatvorené, musí byt' natrvalo označený mikročipom alebo tetovaním. Tie zabezpečujú jednoznačnú identifikáciu psa. Č́íslo čipu je zároveň zapísané v takzvanom pet passporte, teda pase spoločenského zvierat’a.

V čase uzatvorenia poistnej zmluvy musí byt' pes zdravý a zaočkovaný proti besnote. Pes v hmotnostnej kategórii nad štyridsat' kilogramov musí byt' mladší ako pät' rokov a pes $\mathrm{s}$ hmotnost'ou do štyridsat' kilogramov mladší ako devät' rokov. Poistit' je možné aj krížencov. Majitelia psov si môžu vybrat' z niekol'kých poistných rizík. Poistenie nákladov na veterinárnu liečbu v prípade choroby, pričom maximálna doba liečby je 30 dní (s výnimkou chronických ochorení) alebo úrazu. Klient si určuje poistný limit pätnást'- až tridsat'pättisíc korún. Ten vyjadruje nárok na úhradu veterinárnych nákladov počas nasledujúcich dvanástich mesiacov a každoročne sa obnovuje. Škody na zdraví sú ošetrené poistným limitom dva milióny korún, $\mathrm{v}$ prípade škody na majetku je to milión a pre ostatné finančné škody pät'stotisíc korún. V závislosti od veku psa je možné získat' zl’avy z ceny poistného, desat' percent pre psíka mladšieho ako jeden rok, pät' percent pre psíkov od jedného do dvoch rokov. [8]

\section{Rozdiely $v$ životnom a neživotnom poistení}

V rámci životného a neživotného poistenia existujú niektoré základné diferencie, na základe ktorých je Doba poistenia: neživotné poistenie - uzatvára sa zvyčajne krátkodobo (poistenie budovy, domácnosti, havarijné poistenie motorových vozidiel - poistné obdobie je spravidla jeden rok) alebo na krátku dobu (poistenie liečebných nákladov v zahraničí); životné poistenie - spravidla dlhodobé, uzatvorené na určitý počet rokov (napr. 10, 20 a pod.)

Tvorba rezervy: neživotné poistenie - ide o rizikové poistenia, čiže z poistného u majetkových a ostatných neživotných zmlúv sa netvorí rezerva. Poistné sa v danom roku spotrebuje na prospech iných klientov, ak sa nestala žiadna poistná udalost'. To platí aj pre pripoistenia $\mathrm{k}$ životným poisteniam (napr. smrt' úrazom, trvalé následky úrazu, čas nevyhnutného liečenia úrazu a pod.), ktoré sú rizikové, čisto náhodné; životné poistenie - z poistného u životných zmlúv sa z dvoch základných rizík, to znamená z „dožitia“ a „akejkol'vek smrti“ tvorí rezerva, ktorá zostáva v poist'ovni počas doby poistenia a klientovi sa sporí a zároveň úročí.

\section{Literatúra}

[1] MAJTÁNOVÁ, A., DAŇHEL, J., A., KUCHÁČKOVÁ, E., KAFKOVÁ, E.: Poistovníctvo - Teória a prax, Ekkopress, Praha, 2006, ISBN 80-86929-19-1 
[2] CHOVAN, P.: poist'ovníctvo v kocke, slovenská asociácia poist'ovní, Bratislava, 2006 ISBN 80-967410-1-2

[3] KOŠŤÁlOVÁ, A., KOVÁČIKOVÁ, M., ŠVÁBOVÁ, L.: Poist'ovníctvo, Žilinská univerzita, Žilina, 2008 ISBN 978-80-8070-805-4

[4] CHOVAN, P.: Teória a prax poistenia, SÚVAHA, Bratislava, 2000, ISBN 80-88727-367

[5] Dostupné na: http://www.samp.sk

[6] Dostupné na: http://www.poistenie.sk

[7] Dostupné na: http://www.obroda.sk/clanok/5253/Positovne-prechadzaju-na-investicnezivotne-poistnia

[8] Dostupné na: http://www.cps.sk

[9] BAJANKOVÁ, A.: Perspektíva produktov neživotného poistenia v rámci elektronického poist'ovníctva, Žilina 2009

\section{Grantová podpora}

